\title{
PENENTUAN KAPASITAS PRODUKSI MENGGUNAKAN METODE FUZZY INFERENCE SYSTEM-TSUKAMOTO
}

\author{
Suseno $^{1}$, Satyo Hega Wibowo ${ }^{2}$ \\ ${ }^{1,2)}$ Fakultas Sains \& Teknologi, Jurusan Teknik Industri, Universitas Teknologi Yogyakarta \\ Jl. Glagahsari no 63 Umbulharjo Yogyakarta \\ Email: suseno@uty.ac.id, satyohega36@gmail.com
}

\begin{abstract}
ABSTRAK
Pada bulan Januari 2019, PT Semen Gresik Rembang menerima permintaan rata- rata untuk semen PPC (Pozzolan Portland Cement) sebesar 4.223 ton/hari. Rata- rata persediaan semen PPC sebesar 32.138 ton/hari. Rata-rata produksi sebesar 4.468 ton/hari. Tingginya kapasitas persediaan tersebut dan besarnya kapasitas rata- rata produksi yang melebihi rata-rata permintaan memberikan dampak pada kapasitas produksi yang melebihi batas maksimum persediaan (overload), yaitu 36.000 ton. Overload terjadi pada tanggal 19 Januari sebesar 36.088 ton, tanggal 20 Januari sebesar 36.578 ton, dan tanggal 21 Januari sebesar 36.865 ton. Penelitian ini bertujuan untuk menentukan kapasitas produksi yang optimum, dimana kapasitas produksi tidak mengakibatkan overload pada persediaan. Overload persediaan berdampak kerugian bagi perusahaan berupa gudang persediaan tidak tersedia serta pengerasan semen. Oleh karena itu perlu upaya perusahaan dalam mengatur kapasitas produksi agar lebih optimal. Metode yang digunakan adalah fuzzy inference system model Tsukamoto. Pembentukan pemodelan dilakukan pada aplikasi microsoft excel. Tahap pembentukan fungsi keanggotaan disesuaikan berdasarkan aturan fuzzy yang dibentuk. Pada tahap inferensi sistem menerapkan perhitungan fungsi minimum dan pada tahap defuzzifikasi menerapkan perhitungan ratarata. Kapasitas rata-rata produksi semen PPC dengan metode fuzzy inference system-Tsukamoto (FISTsukamoto) sebesar 4.195,48 ton/hari yang memberikan persediaan akhir semen PPC yang optimum.
\end{abstract}

Kata Kunci: Fuzzy Inference System-Tsukamoto, permintaan, persediaan, produksi

\begin{abstract}
In January 2019, PT Semen Gresik Rembang received an average demand for PPC cement (Pozzolan Portland Cement) of 4,223 tons / day, while the average PPC cement supply was 32,138 tons / day. The average production is 4,468 tons / day. The high inventory capacity and the large average production capacity that exceeds the average demand have an impact on production capacity that exceeds the maximum inventory limit (36,000 tons). Overload occurred on January 19 at 36,088 tons, January 20 at 36,578 tons, and January 21 at 36,865 tons. This study aims to determine the optimum production capacity, where production capacity does not result in overload on inventory. Inventory overload has a detrimental effect on companies in the form of unavailable inventory warehouse and hardening of cement. Therefore it is necessary for the company's efforts to regulate production capacity to be more optimal. The method used is the Tsukamoto model fuzzy inference system. Formation of modeling is done on Microsoft Excel applications. The stage of forming membership functions is adjusted based on fuzzy rules that are formed. In the inference stage the system applies the minimum function calculation and at the defuzzification stage applies the average calculation. The average capacity of PPC cement production with the Tsukamoto fuzzy inference system method is 4,195.48 tons / day which provides the optimum end of PPC cement supply.
\end{abstract}

Keywords: Fuzzy Inference System-Tsukamoto, demand, purchase, production

\section{PENDAHULUAN}

PT Semen Gresik Rembang adalah salah satu anak perusahaan dari PT Semen Indonesia yang memproduksi semen jenis PPC (Portland Pozzoland Cement) dan OPC (Ordinary Portland Cement). Dalam kegiatan produksinya, PT Semen Gresik Rembang tidak menerima secara langsung jumlah permintaan dari konsumen, melainkan hanya menerima permintaan pesanan semen dari PT Semen Indonesia. 
Pada bulan Januari 2019, PT Semen Gresik Rembang menerima permintaan rata-rata untuk semen PPC sebesar 4.223 ton/hari. Pada saat itu, rata-rata persediaan semen PPC sebesar 32.138 ton/hari dengan rata-rata produksi sebesar 4.468 ton/hari. Tingginya kapasitas persediaan tersebut dan besarnya kapasitas rata-rata produksi yang melebihi rata-rata permintaan memberikan dampak pada kapasitas produksi yang melebihi batas maksimum persediaan (overload), yaitu 36.000 ton. Overload terjadi pada tanggal 19 Januari sebesar 36.088 ton, tanggal 20 Januari sebesar 36.578 ton, dan tanggal 21 Januari sebesar 36.865 ton.

Overload yang terjadi mengakibatkan bertambahnya biaya penyimpanan semen, penuhnya tempat penyimpanan semen, dan meningkatnya kemungkinan terjadi pengerasan semen. Agar overload tidak terjadi kembali, maka perlu dilakukan perencanaan untuk menentukan kapasitas produksi dengan sebuah pemodelan. Salah satunya adalah menggunakan logika fuzzy inference system (FIS).

Kondisi overload ini kebalikan dari studi kasus hasil penelitian Mulyanto (2016) pada perusahaan yang kapasitas produksinya beberapa kali tidak bisa memenuhi permintaan, sehingga hasil rekomendasi menggunakan metode FIS-Tsukamoto adalah jam lembur (overtime) dalam memenuhi permintaan, sekaligus dapat menentukan jumlah persediaan dalam menunjang kelancaran jalannya produksi.

Logika fuzzy itu sendiri merupakan logika yang berhadapan dengan konsep kebenaran sebagian, dimana logika klasik menyatakan bahwa segala hal dapat diekspresikan dalam istilah binary (0 atau 1). Logika fuzzy memungkinkan nilai keanggotaan antara 0 sampai 1. Berbagai teori perkembangan logika fuzzy menunjukkan bahwa pada dasarnya logika fuzzy dapat digunakan untuk memodelkan berbagai sistem. (Bahroni, dkk, 2016)

Ada beberapa logika fuzzy yang sudah dipelajari, namun perancangan menggunakan fuzzy tsukamoto lebih banyak dijadikan rujukan dikarenakan penentuan model inference harus tepat. Fuzzy mamdani umumnya cocok untuk permasalahan intuitive, fuzzy sugeno untuk permasalahan yang menangani control, sedangkan fuzzy tsukamoto untuk rekomendasi. (Suyanto,2007)

Metode Tsukamoto dapat dikatakan sebagai logika fuzzy yang paling efisien untuk diterapkan pada sebuah pemodelan. Hal ini dikarenakan metode Tsukamoto memiliki sistem inferensi yang paling mudah dimodelkan dibandingkan dengan metode Mamdani dan Sugeno. Melalui microsoft excel akan dilakukan pemodelan fuzzy inference system-Tsukamoto (FIS-Tsukamoto) untuk menentukan kapasitas produksi semen, karena metode ini banyak dimanfaatkan oleh berbagai bidang tak terkecuali pada bidang perekonomian (Kaswidjanti, 2015).

Dengan menggunakan fuzzy inference system-Tsukamoto, kapasitas produksi akan ditentukan dengan pertimbangan nilai minimum dan maksimum dari permintaan yang diterima, persediaan silo semen, dan kemampuan produksi perusahaan. Sehingga nilai kapasitas produksi yang diperoleh dapat diatur sesuai rule yang nantinya ditentukan berdasarkan kondisi jumlah permintaan dan persediaan perusahaan saat itu.

Bahroni (2016) menjelaskan bahwa Logika fuzzy memiliki derajat keanggotaan dalam rentang 0 hingga 1. Berbeda dengan logika digital yang hanya memiliki dua nilai 1 atau 0 . Logika fuzzy digunakan untuk menerjemahkan suatu besaran yang diekspresikan menggunakan bahasa (linguistic), misalkan besaran kecepatan laju kendaraan yang diekspresikan dengan pelan, agak cepat, cepat, dan sangat cepat. Dan logika fuzzy menunjukan sejauh mana suatu nilai itu benar dan sejauh mana suatu nilai itu salah. Logika fuzzy adalah suatu cara yang tepat untuk memetakan suatu ruang input kedalam suatu ruang output. Fuzzy dinyatakan dalam derajat dari suatu keanggotaan dan derajat dari kebenaran. Oleh sebab itu sesuatu dapat dikatakan sebagian benar dan sebagian salah pada waktu yang sama.

Tahapan-tahapan dalam metode Fuzzy yang digunakan yaitu sebagai berikut:

\subsection{Pembentukan Himpunan Fuzzy}

Pada tahapan ini variabel input dari sistem fuzzy dibuat ke dalam himpunan fuzzy untuk dapat digunakan dalam perhitungan. Pada tahap ini menentukan derajat keanggotaan dari setiap himpunan fuzzy.

Fungsi keanggotaan (membership function) adalah suatu kurva yang menunjukkan pemetaan titik-titik input data ke dalam nilai keanggotaannya yang memiliki interval antara 0 sampai (Kusumadewi, 2013). Himpunan fuzzy yang digunakan dalam penelitian ini menggunakan 3 fungsi keanggotaan menurut Ramlan (2016) dan Yusida (2017), yaitu:

\section{A. Fungsi linear turun}

Fungsi linear turun merupakan himpunan dimulai pada nilai domain yang memiliki derajat keanggotaan satu kemudian bergerak ke kanan menuju ke derajat keanggotaan nol. 


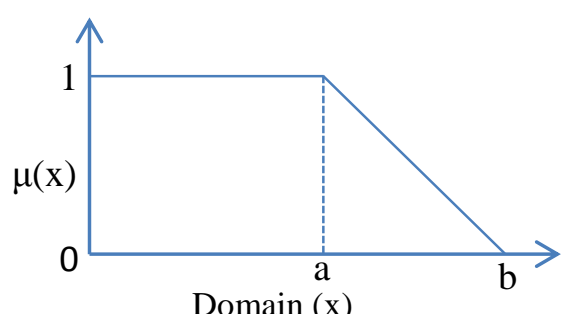

Gambar 1. Fungsi Linear Turun

Berdasarkan fungsi linear turun dapat diketahui bahwa ketika nilai domain $(\mathrm{x}) \leq a$ maka nilai keanggotaan $(\mu)$ adalah 1 . Jika nilai domain $(\mathrm{x}) \geq a$ maka nilai keanggotaan $(\mu)$ adalah 0 . Jika nilai domain (x) diantara a dan b maka nilai keanggotaannya adalah $\frac{(b-x)}{(b-a)}$. Secara ringkas dapat jabarkan pada persamaan 1 .

$$
\mu(x)=\left\{\begin{array}{cc}
1 ; & x \leq a \\
(b-x) /(b-a) & a \leq x \geq b \\
0 ; & x \geq b
\end{array}\right.
$$

\section{B. Fungsi linear naik}

Fungsi linear naik merupakan himpunan dimulai pada nilai domain yang memiliki derajat keanggotaan nol kemudian bergerak ke kanan menuju ke derajat keanggotaan satu.

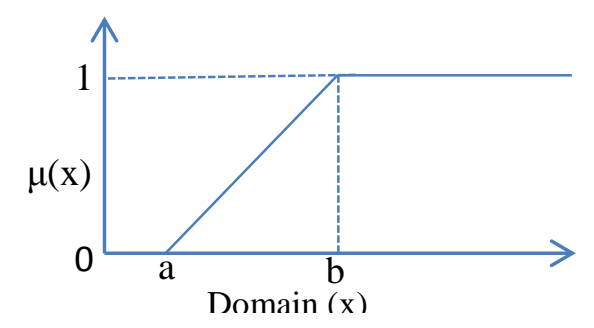

Gambar 2. Fungsi Linear Naik

Dari fungsi linear turun dapat diketahui bahwa ketika nilai domain $(\mathrm{x}) \leq a$ maka nilai keanggotaan $(\mu)$ adalah 0 . Jika nilai domain $(\mathrm{x}) \geq a$ maka nilai keanggotaan $(\mu)$ adalah 1 . Jika nilai domain $(\mathrm{x})$ diantara a dan b maka nilai keanggotaannya adalah $\frac{(x-a)}{(b-a)}$. Secara ringkas dapat jabarkan pada persamaan 2 .

$$
\mu(x)=\left\{\begin{array}{cc}
0 ; & x \leq a \\
(x-a) /(b-a) & a \leq x \geq b \\
1 ; & x \geq b
\end{array}\right.
$$

\section{Fungsi segitiga}

Kurva segitiga pada dasarnya merupakan gabungan antara 2 garis linear naik dan turun.

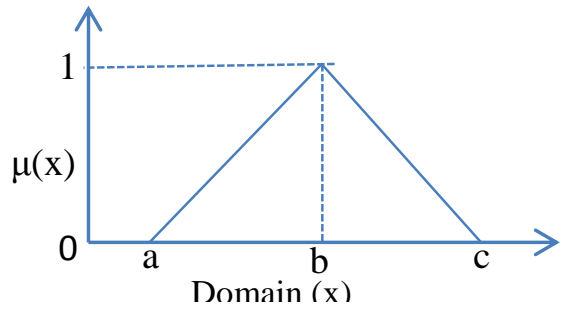

Gambar 3. Fungsi Linear Segitiga

Dari fungsi linear segitiga dapat diketahui bahwa ketika nilai domain $(\mathrm{x}) \leq a$ atau $\geq c$ maka nilai keanggotaan $(\mu)$ adalah 0 . Jika nilai domain (x) diantara a dan b maka nilai keanggotaannya adalah 
$\frac{(x-a)}{(b-a)}$. Jika nilai domain $(\mathrm{x})$ diantara $\mathrm{b}$ dan $\mathrm{c}$ maka nilai keanggotaannya adalah $\frac{(b-x)}{(b-a)}$. Secara ringkas dapat jabarkan pada persamaan 3.

$$
\mu(x)=\left\{\begin{array}{cc}
0 ; & x \leq \text { a atau } x \geq c \\
(x-a) /(b-a) & a \leq x \leq b \\
(b-x) /(c-b) & b \leq x \leq c
\end{array}\right.
$$

\subsection{Inference System Rules}

Hasil dari proses perhitungan nilai keanggotaan fuzzy kemudian diinferensikan terhadap aturan-aturan fuzzy (rules). Pada metode Tsukamoto, fungsi implikasi yang digunakan adalah min. Perhitungan jumlah rules adalah dengan mengalikan jumlah himpunan fuzzy (dua variabel linguistik) sebanyak jumlah variabel input.

$$
\alpha-\text { predikat }_{i}=\mu_{A 1 \cap A 2}=\min \left(\mu_{A 1}\left(x_{1}\right), \mu_{A 2}\left(x_{2}\right)\right)
$$

\subsection{Defuzzyfication}

Untuk mendapatkan nilai output (crisp) adalah dengan mengubah input menjadi suatu bilangan pada domain himpunan fuzzy tersebut atau yang dimaksud dengan defuzifikasi. Setelah diperoleh nilai $\alpha$ i, maka selanjutnya akan dilakukan proses perhitungan nilai setiap konsekuen setiap rules (zi) sesuai dengan fungsi keanggotaan yang digunakan. Metode defuzifikasi dalam metode Tsukamoto adalah defuzzifikasi rata-rata terpusat (Center Average Defuzzyfier).

$$
Z=\frac{\sum_{i=1}^{n} \alpha_{i} z_{i}}{\sum_{i=1}^{n} \alpha_{i}}
$$

Dimana pada persamaan di atas, $\mathrm{Z}$ merupakan hasil deffuzifikasi, sedangkan $\alpha$ i adalah nilai keanggotaan antiseden, dan zi adalah hasil inferensi tiap aturan.

\section{METODE PENELITIAN}

Berdasarkan gambar 4 maka dapat dijelaskan alur proses sistem adalah sebagai berikut :

1. Input berupa pengumpulan data batas maksimum, minimum dan rata-rata dari permintaan, persediaan, dan kapasitas produksi. Teknik pengumpulan data yang digunakan adalah wawancara dan dokumentasi.

2. Dari inputan yang diterima maka akan dilakukan proses fuzzifikasi. Yaitu mencari nilai keanggotaan dengan menggunakan fungsi keanggotaan himpunan fuzzy dengan memperhatikan nilai maksimum dan minimum dari tiap variabel

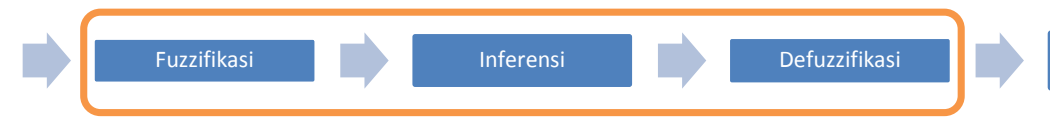

Gambar 4. Alur Proses Aplikasi (Anggun, 2016)

3. Langkah berikutnya dilakukan inferensi.

4. Setelah proses inferensi maka akan dilakukan proses defuzzifikasi, yaitu untuk menentukan output crisp menggunakan defuzzifikasi rata-rata terpusat.

5. Selanjutnya hasil perhitungan ditampilkan berupa kapasitas produksi yang optimal

\section{HASIL DAN PEMBAHASAN}

Data yang digunakan merupakan data dari hasil wawancara kepada pembimbing PT Semen Gresik Rembang dan dokumentasi data produksi semen selama bulan Januari 2019.

Dari wawancara diperoleh data batas maksimum dan minimum dari permintaan, persediaan, dan produksi semen. Berikut adalah data batas maksimum dan minimum dari permintaan, persediaaan, dan produksi.

Tabel 2. Data Batasan Faktor

\begin{tabular}{ccccc}
\hline \multirow{2}{*}{ Jenis Semen } & \multirow{2}{*}{ Batas } & \multicolumn{3}{c}{ Faktor } \\
\cline { 3 - 5 } & & $\begin{array}{c}\text { Permintaan Semen } \\
\text { (ton) }\end{array}$ & $\begin{array}{c}\text { Persediaan Silo Semen } \\
\text { (ton) }\end{array}$ & $\begin{array}{c}\text { Produksi Semen } \\
\text { (ton/hari) }\end{array}$ \\
\hline \multirow{2}{*}{ PPC } & Maksimum & 8.000 & 36.000 & 10.000 \\
& Minimum & 2.000 & 20.000 & 300 \\
\hline
\end{tabular}


Berdasarkan permintaan semen dari PT Semen Indonesia ke PT Semen Gresik dari tahun 2017 hingga sekarang, diketahui bahwa permintaan maksimum semen PPC sebesar 8.000 ton. Minimum permintaan semen PPC sebesar 2.000 ton. Pada PT Semen Gresik Rembang terdapat 3 silo semen yang berfungsi sebagai tempat penyimpanan persediaan semen sementara. Dua diantaranya adalah silo semen untuk jenis PPC dan salah satunya untuk jenis semen OPC. Setiap silo diberikan batasan minimum persediaan untuk safety stock sebesar 10.000 ton/silo dan batas maksimumnya 18.000 ton/silo. Kapasitas produksi maksimum semen PPC sebesar 10.000 ton/hari. Kapasitas produksi minimum untuk semen PPC.

Data kapasitas produksi, permintaan, dan persediaan yang ada selama 30 hari pada bulan Januari. tercantum pada tabel 3 .

Tabel 3. Dokumentasi Data Produksi Semen Bulan Januari 2019

\begin{tabular}{|c|c|c|c|}
\hline \multirow{2}{*}{ Tanggal } & \multicolumn{3}{|c|}{ Semen PPC } \\
\hline & Permintaan (ton) & Persediaan (ton) & Produksi (ton) \\
\hline 1 & 1.368 & 33.394 & 4.621 \\
\hline 2 & 4.620 & 31.390 & 1.645 \\
\hline 3 & 5.992 & 29.718 & 4.320 \\
\hline 4 & 6.016 & 28.525 & 4.824 \\
\hline 5 & 3.612 & 30.569 & 5.680 \\
\hline 6 & 3.124 & 31.643 & 5.373 \\
\hline 7 & 5.160 & 32.380 & 5.962 \\
\hline 8 & 6.264 & 33.748 & 6.088 \\
\hline 9 & 6.140 & 33.815 & 8.728 \\
\hline 10 & 6.204 & 33.097 & 8.703 \\
\hline 11 & 5.352 & 33.306 & 4.928 \\
\hline 12 & 3.256 & 32.879 & 2.957 \\
\hline 13 & 2.692 & 30.187 & 0 \\
\hline 14 & 4.160 & 27.698 & 1.671 \\
\hline 15 & 5.164 & 26.211 & 3.514 \\
\hline 16 & 6.512 & 24.334 & 4.690 \\
\hline 17 & 4.820 & 31.367 & 9.380 \\
\hline 18 & 4.440 & 32.059 & 7.058 \\
\hline 19 & 2.944 & 36.088 & 6.427 \\
\hline 20 & 2.228 & 36.578 & 2.192 \\
\hline 21 & 3.184 & 36.865 & 1.088 \\
\hline 22 & 4.020 & 32.236 & 701 \\
\hline 23 & 4.616 & 28.159 & 540 \\
\hline 24 & 3.692 & 29.761 & 5.293 \\
\hline 25 & 3.844 & 32.231 & 6.314 \\
\hline 26 & 2.856 & 34.296 & 4.921 \\
\hline 27 & 1.360 & 33.921 & 1.485 \\
\hline 28 & 3.856 & 34.859 & 4.762 \\
\hline 29 & 4.700 & 34.532 & 5.234 \\
\hline 30 & 4.520 & 34.422 & 4.567 \\
\hline 31 & 4.212 & 34.605 & 4.836 \\
\hline Rata-Rata & $4.223,48$ & 32.138 & 4.468 \\
\hline
\end{tabular}

Pada tabel 3 dapat dilihat bahwa pada tanggal 19, 20, dan 21 Januari 2019 terjadi overload persediaan semen PPC secara berturut-turut sebesar 36.088 ton, 36.578 ton, dan 36.865 ton yang melebihi batas maksimum persediaan

\subsection{Pengolahan Data}

Pengolahan data Fuzzy Inference System-Tsukamoto terdiri dari 4 tahap utama, yaitu pembentukan fungsi keanggotaan, penentuan nilai keanggotaan, sistem inferensi, dan defuzzyfikasi.

\subsection{Input Data Permintaan dan Persediaan}

Data yang menjadi input pemodelan sistem ini adalah data permintaan dan data persediaan semen. Data permintaan semen bulan Januari 2019 ditampilkan pada tabel 3 dan data persediaan awal semen pada hari ke$\mathrm{n}$ adalah "STOK SEMEN SEBELUM PRODUKSI" sebesar 33.552,15 ton. 
Data persediaan yang dimasukkan hanyalah data persediaan pada tanggal 1 Januari 2019. Data persediaan pada hari selanjutnya yang sudah ada nantinya akan berbeda dengan data sisa persediaan hasil pengolahan data FIS-Tsukamoto.

\subsection{Input Data Batasan}

Input data berikutnya adalah data batasan maksimum dan minimum dari permintaan, persediaan, dan produksi semen. Input data ini diletakkan pada bawah tabel pengolahan data. Data batasan permintaan, persediaan, dan produksi berdasarkan data yang ada pada tabel 2.

\subsection{Fungsi Keanggotaan}

Fungsi keanggotaan dibentuk berdasarkan rule (aturan) yang ditentukan untuk memperoleh nilai $z$ (tujuan) (Oktaviani, 2014). Aturan yang digunakan dalam penelitian ini untuk menentukan kapasitas produksi dapat dilihat pada tabel 4 .

Tabel 4. Aturan Fuzzy

\begin{tabular}{|l|l|l|l|c|l|c|}
\hline R1 & Jika Permintaan & Turun & dan Persediaan & Banyak & Maka Produksi & Berkurang \\
\hline R2 & Jika Permintaan & Turun & dan Persediaan & Sedikit & Maka Produksi & Bertambah \\
\hline R3 & Jika Permintaan & Naik & dan Persediaan & Banyak & Maka Produksi & Berkurang \\
\hline R4 & Jika Permintaan & Naik & dan Persediaan & Sedikit & Maka Produksi & Bertambah \\
\hline
\end{tabular}

Dimana R1 adalah rule pertama, R2 adalah rule kedua, R3 adalah rule ketiga, dan R4 adalah rule keempat. Berdasarkan aturan fuzzy pada tabel 4 , terdapat 3 variabel fuzzy yang akan dimodelkan, yaitu permintaan, persediaan, dan produksi. Untuk membentuk fungsi keanggotaan fuzzy, perlu dibuat grafik fungsi keanggotaan setiap variabel untuk mempermudah menentukan fungsi keanggotannya. Grafik fungsi keanggotaan yang dibuat berdasarkan batasan yang ada pada tabel 2.

1. Fungsi Keanggotaan Variabel Permintaan Semen PPC

Fungsi keanggotaan variabel permintaan semen PPC memiliki batas maksimum 8.000 ton dan batas minimum 2.000 ton semen.

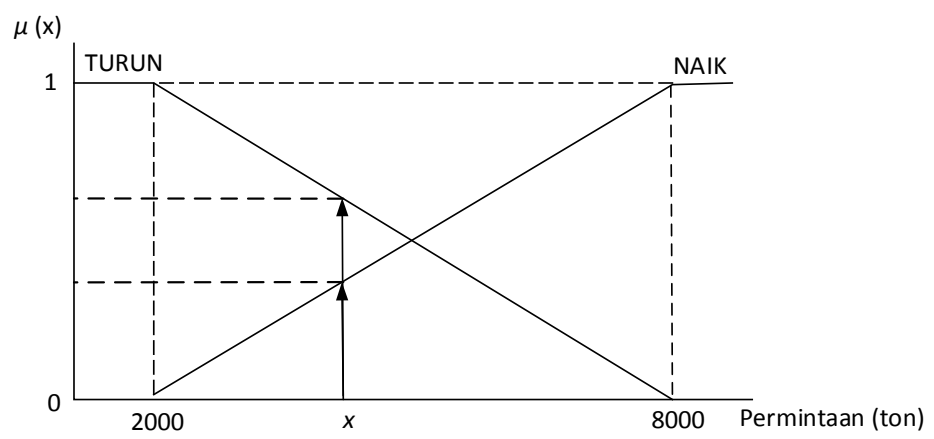

Gambar 5. Fungsi Keanggotaan Variabel Permintaan Semen PPC

Berdasarkan grafik gambar 5 maka dapat disimpulkan bahwa nilai keanggotaan $\mu$ permintaan semen PPC memiliki batasan sebagai berikut:

$$
\begin{aligned}
& \operatorname{\mu pmtPPCTurun}[x]=\left\{\begin{array}{crr}
1 & , & x \leq 2.000 \\
\frac{8.000-x}{6.000} & , 2.000 & \leq x \leq 8.000 \\
0 & , & x \geq 8.000
\end{array}\right. \\
& \mu p m t P P C N a i k[x]=\left\{\begin{array}{crr}
0 & , & x \leq 2.000 \\
\frac{x-2.000}{6.000} & , 2.000 & \leq x \leq 8.000 \\
1 & , & x \geq 8.000
\end{array}\right.
\end{aligned}
$$

Setelah dibentuk batasan nilai keanggotaan $\mu$ permintaan semen PPC, kemudian dibentuk formula pada microsoft excel. Berikut ini adalah contoh formula untuk $\mu$ mtPPCTurun $[x]$ dan $\mu$ pmtPPCNaik $[x]$ pada tanggal 1 Januari 2019.
a. Pada kolom $\mu$ pmtPPCTurun $[x]$ $=\mathrm{IF}(\mathrm{B} 6<=\$ \mathrm{~B} \$ 44,1, \mathrm{IF}(\mathrm{B} 6<=\$ \mathrm{~B} \$ 43,(\$ \mathrm{~B} \$ 43-\mathrm{B} 6) /(\$ \mathrm{~B} \$ 43-\$ \mathrm{~B} \$ 44), 0))$
b. Pada kolom $\mu$ pmtPPCNaik $[x]$ $=\mathrm{IF}(\mathrm{B} 6<=\$ \mathrm{~B} \$ 44,0, \mathrm{IF}(\mathrm{B} 6<=\$ \mathrm{~B} \$ 43,(\mathrm{~B} 6-\$ \mathrm{~B} \$ 44) /(\$ \mathrm{~B} \$ 43-\$ \mathrm{~B} \$ 44), 1))$ 
2. Fungsi Keanggotaan Variabel Persediaan Semen PPC

Fungsi keanggotaan variabel persediaan semen PPC memiliki batas maksimum 36.000 ton dan batas minimum 20.000 ton semen.

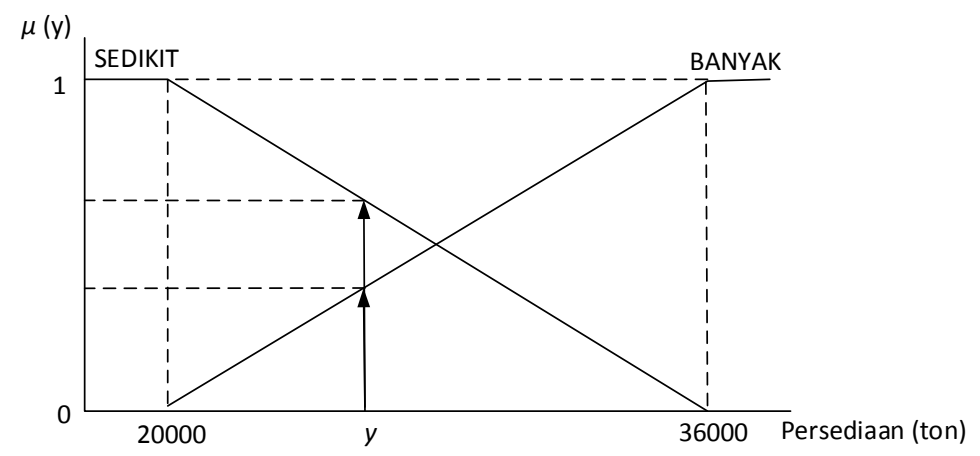

Gambar 6. Fungsi Keanggotaan Variabel Persediaan Semen PPC

Berdasarkan grafik gambar 6 maka dapat disimpulkan bahwa nilai keanggotaan $\mu$ persediaan semen PPC memiliki batasan sebagai berikut:

$$
\begin{aligned}
& \text { upsdPPCSedikit }[y]=\left\{\begin{array}{ccc}
1 & , & y \leq 20.000 \\
\frac{36.000-y}{16.000} & , 20000 & \leq y \leq 36.000 \\
0 & , & y \geq 36.000
\end{array}\right.
\end{aligned}
$$

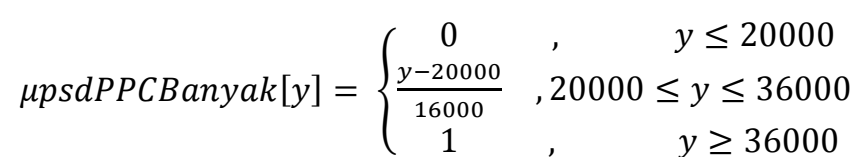

Setelah dibentuk batasan nilai keanggotaan $\mu$ persediaan semen PPC, kemudian dibentuk formula pada microsoft excel. Berikut ini merupakan contoh formula untuk $\mu p s d P P C S e d i k i t[y]$ dan $\mu p s d P P C B a n y a k[y]$ pada tanggal 1 Januari 2019.

a. Pada kolom $\mu$ psdPPCSedikit $[y]$

$$
=\mathrm{IF}(\mathrm{D} 6<=\$ \mathrm{D} \$ 44,1, \mathrm{IF}(\mathrm{D} 6<=\$ \mathrm{D} \$ 43,(\$ \mathrm{D} \$ 43-\mathrm{D} 6) /(\$ \mathrm{D} \$ 43-\$ \mathrm{D} \$ 44), 0))
$$

b. Pada kolom $\mu$ ssdPPCBanyak $[y]$

$$
=\mathrm{IF}(\mathrm{D} 6<=\$ \mathrm{D} \$ 44,0, \mathrm{IF}(\mathrm{D} 6<=\$ \mathrm{D} \$ 43,(\mathrm{D} 6-\$ \mathrm{D} \$ 44) /(\$ \mathrm{D} \$ 43-\$ \mathrm{D} \$ 44), 1))
$$

\section{Fungsi Keanggotaan Variabel Produksi Semen PPC}

Fungsi keanggotaan variabel produksi semen PPC memiliki batas maksimum 10.000 ton dan batas minimum 300 ton semen.

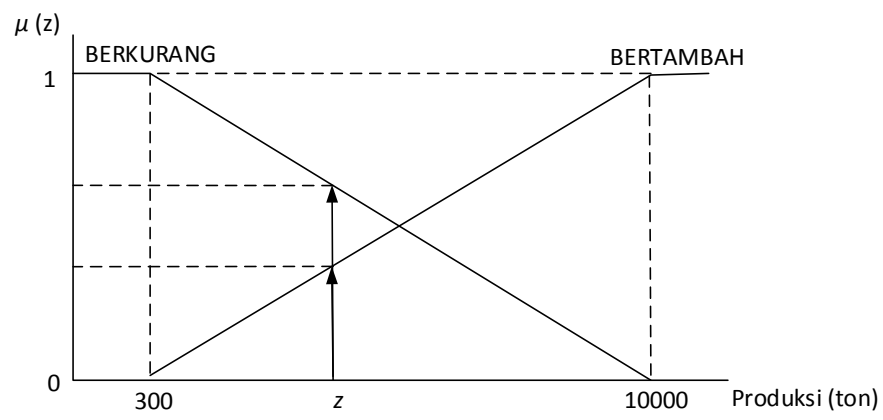

Gambar 7. Fungsi Keanggotaan Variabel Produksi Semen PPC

Berdasarkan grafik gambar 7 maka dapat disimpulkan bahwa nilai keanggotaan $\mu$ produksi semen PPC memiliki batasan sebagai berikut:

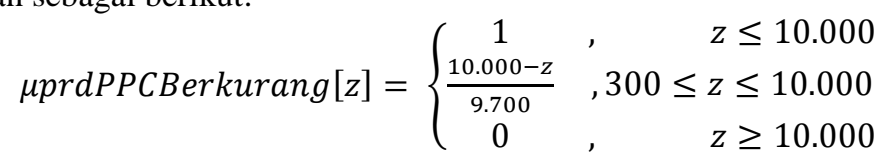




$$
\mu p r d P P C B e r t a m b a h[z]=\left\{\begin{array}{crr}
0 & , \quad z \leq 10.000 \\
\frac{z-300}{9.700} & , 300 \leq & z \leq 10.000 \\
1 & , & z \geq 10.000
\end{array}\right.
$$

Fungsi keanggotaan variabel produksi semen PPC nantinya akan digunakan dalam proses inferensi sistem.

\subsection{Nilai Keanggotaan}

Setelah dibentuk formula dari fungsi keanggotaan permintaan dan permintaan, kemudian diperoleh nilai keanggotaan dari setiap aturan. Nilai keanggotaan yang dicari adalah nilai keanggotaan dari permintaan dan persediaan. Nilai keanggotaan yang diperoleh berbeda-beda tergantung dari data permintaan dan persediaan yang ada pada saat itu. Nilai keanggotaan permintaan turun bernilai 1 apabila data permintaan $\leq$ batas minimum permintaan 2.000 ton. Nilai keanggotaan permintaan turun bernilai 0 apabila data permintaan $\geq$ batas maksimum 8.000 ton. Nilai keanggotan persediaan sedikit bernilai 1 apabila data persediaan $\leq$ batas minimum 20.000 ton. Nilai keanggotaan persediaan turun sedikit bernilai 0 apabila data permintaan $\geq$ batas maksimum 36.000 ton. Nilai keanggotaan permintaan naik dan persediaan banyak bernilai kebalikan dari nilai keanggotaan permintaan turun dan persediaan sedikit. Apabila data terletak diantara batas minimum dan maksimum, maka akan dihitung berdasarkan persamaan 1 dan 2.

Berikut ini adalah hasil dari $\mu$ permintaan turun, $\mu$ permintaan naik, $\mu$ persediaan sedikit, serta $\mu$ persediaan banyak.

Tabel 5. Nilai Keanggotaan

\begin{tabular}{|c|c|c|c|c|}
\hline \multirow{3}{*}{ TGL } & \multicolumn{4}{|c|}{ FUNGSI KEANGGOTAAN } \\
\cline { 2 - 5 } & PRMNT TURUN & PRMNT NAIK & PSD SEDIKIT & PSD BANYAK \\
\cline { 2 - 5 } & PRAC & 0.15 & 0.85 \\
\hline 1 & 1.00 & 0.00 & \multicolumn{4}{|c|}{} \\
\hline
\end{tabular}

Sebagai contoh, permintaan semen PPC pada tanggal 1 Januari sebesar 1.368 ton, berdasarkan fungsi keanggotaan $\mu$ permintaan turun PPC $1.368<2.000$, maka nilai $\mu$ permintaan turun PPC adalah 1.

\subsection{Inferensi Sistem}

Tahap infrence system merupakan tahap penentuan nilai $\alpha$ - predikat $_{i}$ terhadap $R_{i}$. Menentukan nilai $\alpha-$ predikat $_{i}$ dirumuskan pada persamaan 4 dengan mencari nilai minimum dari setiap variabel menurut aturan fuzzy-nya. Berikut merupakan inference system PPC pada tanggal 1 Januari 2019 sebagai contoh pembentukan formulanya.

1. Inferensi Aturan Pertama

Pada atauran pertama, "jika permintaan turun dan persediaan banyak, maka produksi berkurang". Berikut ini merupakan contoh perhitungan inferensi sistem aturan pertama untuk data semen PPC pada tanggal 1 Januari 2019.

$$
\begin{aligned}
\alpha-\text { predikat }_{1} P P C & =\mu_{\text {pmtPPCTurunnpsdPPCBanyak }} \\
& =\min \left(\mu_{\text {pmtPPCTurun }}\left(x_{1}\right), \mu_{\text {psdPPCBanyak }}\left(x_{2}\right)\right) \\
& =\min \left(\mu_{\text {pmtTurun }}(1.368), \mu_{\text {psdBanyak }}(33.552,15)\right) \\
& =\min (1 ; 0,85) \\
& =0,85
\end{aligned}
$$

Formula untuk $\alpha-$ predikat $_{1} P P C$ adalah $=\mathrm{MIN}(\mathrm{F} 6, \mathrm{I6})$

Pada aturan pertama dikatakan produksi berkurang, jadi perhitungan $z_{1}$ menggunakan fungsi keanggotaan $(\mu)$ produksi berkurang.

$$
\begin{aligned}
& \text { uprdBerkurang }[z]=\frac{10.000-z_{1}}{9.700} \\
& \text { uprdBerkurang }[z] \times 9.700=10.000-z_{1} \\
& z_{1}=10.000-(\mu \text { prdBerkurang }[z] \times 9.700) \\
& z_{1}=10.000-(0,85 \times 9.700) \\
& z_{1}=1.784,01
\end{aligned}
$$

Pada perhitungan $z_{1}$ diperoleh persamaan $z_{1}=10.000-(\mu p r d B e r k u r a n g[z] \times 9.700)$, maka dapat dibuat formula sebagai berikut:

$$
\begin{aligned}
& =\mathrm{IF}(\text { Sheet } 1 \text { ! J \$31="BERKURANG",\$AE\$43((\$AE\$43\$AE\$44)*N6),IF(Sheet1!\$J \$1="B } \\
& \text { ERTAMBAH",((\$AE\$43\$AE\$44)*N6)+\$AE\$44)) }
\end{aligned}
$$

2. Inferensi Aturan Kedua 
Pada atauran kedua, “jika permintaan turun dan persediaan sedikit, maka produksi bertambah”. Berikut ini merupakan contoh perhitungan inferensi sistem aturan kedua untuk data semen PPC pada tanggal 1 Januari 2019.

$$
\begin{aligned}
\alpha-\text { predikat }_{2} P P C & =\mu_{\text {pmtPPCTurun } p \text { sdPPCSedikit }} \\
& =\min \left(\mu_{\text {pmtPPCTurun }}\left(x_{1}\right), \mu_{\text {psdPPCSedikit }}\left(x_{2}\right)\right) \\
& =\min \left(\mu_{\text {pmtTurun }}(1.368), \mu_{\text {psdSedikit }}(33.552,15)\right) \\
& =\min (1 ; 0,15) \\
& =0,15
\end{aligned}
$$

Formula untuk $\alpha-$ predikat $_{2} P P C$ adalah $=\mathrm{MIN}(\mathrm{F} 6, \mathrm{H} 6)$

Aturan kedua dikatakan produksi bertambah, jadi perhitungan $z_{2}$ menggunakan fungsi keanggotaan $(\mu)$ produksi bertambah.

$$
\begin{aligned}
& \text { uprdBertambah }[z]=\frac{z_{2}-300}{9.700} \\
& \mu p r d B e r t a m b a h[z] \times 9.700=z_{2}-300 \\
& z_{2}=(\mu p r d B e r t a m b a h[z] \times 9.700)+300 \\
& z_{2}=(0,15 \times 9.700)+300 \\
& z_{2}=1.784,01
\end{aligned}
$$

Pada perhitungan $z_{2}$ diperoleh persamaan $z_{2}=(\mu p r d B e r t a m b a h[z] \times 9.700)+300$, maka dapat dibuat formula sebagai berikut:

\section{Inferensi Aturan Ketiga}

$$
\begin{aligned}
& =\mathrm{IF}(\text { Sheet } 1 \text { ! J } \$ 32=" B E R K U R A N G ", \$ A E \$ 43-((\$ A E \$ 43 \$ A E \$ 44) * O 6), I F(\text { Sheet } 1 ! \\
& \text { \$J } \$ 32=" B E R T A M B A H ",((\$ A E \$ 43-\$ A E \$ 44) * 06)+\$ A E \$ 44))
\end{aligned}
$$

Pada atauran ketiga, “jika permintaan naik dan persediaan banyak, maka produksi berkurang”. Berikut ini merupakan contoh perhitungan inferensi sistem aturan ketiga untuk data semen PPC pada tanggal 1 Januari 2019.

$$
\begin{aligned}
\alpha-\text { predikat }_{3} P P C & =\mu_{\text {pmtPPCNaiknpsdPPCBanyak }} \\
& =\min \left(\mu_{\text {pmtPPCNaik }}\left(x_{1}\right), \mu_{\text {psdPPCBanyak }}\left(x_{2}\right)\right) \\
& =\min \left(\mu_{\text {pmtNaik }}(1.368), \mu_{\text {psdBanyak }}(33.552,15)\right) \\
& =\min (0 ; 0,99) \\
& =0
\end{aligned}
$$

Formula untuk $\alpha-$ predikat $_{3} P P C$ adalah $=$ MIN(G6,I6)

Aturan ketiga dikatakan produksi berkurang, jadi perhitungan $z_{3}$ menggunakan fungsi keanggotaan $(\mu)$ produksi berkurang.

$$
\begin{aligned}
& \text { uprdBerkurang }[z]=\frac{10.000-z_{3}}{9.700} \\
& \text { } \mu \text { prdBerkurang }[z] \times 9.700=10.000-z_{3} \\
& z_{3}=10.000-(\mu p r d B e r k u r a n g[z] \times 9.700) \\
& z_{3}=10.000-(0 \times 9.700) \\
& z_{3}=10.000
\end{aligned}
$$

Pada perhitungan $z_{3}$ diperoleh persamaan $z_{3}=10.000-($ pprdBerkurang $[z] \times 9.700)$, maka dapat dibuat formula sebagai berikut:

$$
\begin{aligned}
& =\mathrm{IF}(\text { Sheet } 1 \text { ! } \$ \text { J } \$ 33=" B E R K U R A N G ", \$ A E \$ 43-((\$ A E \$ 43-\$ A E \$ 44) * \\
& \text { P6),IF(Sheet1!\$J \$33="BERTAMBAH",((\$AE\$43-\$AE\$44)*P6)+\$AE\$44)) }
\end{aligned}
$$

4. Inferensi Aturan Keempat

Pada atauran keempat, "jika permintaan naik dan persediaan sedikit, maka produksi bertambah". Berikut ini merupakan contoh perhitungan inferensi sistem aturan keempat untuk data semen PPC pada tanggal 1 Januari 2019.

$$
\begin{aligned}
\alpha-\text { predikat }_{4} P P C & =\mu_{\text {pmtPPCNaiknpsdPPCSedikit }} \\
& =\min \left(\mu_{\text {pmtPPCNaik }}\left(x_{1}\right), \mu_{\text {psdPPCSedikit }}\left(x_{2}\right)\right) \\
& =\min \left(\mu_{\text {pmtNaik }}(1.368), \mu_{\text {psdSedikit }}(33.552,15)\right) \\
& =\min (0 ; 0,15) \\
& =0
\end{aligned}
$$

Formula untuk $\alpha-$ predikat $_{4} P P C$ adalah $=\mathrm{MIN}(\mathrm{G} 6, \mathrm{H} 6)$

Aturan keempat dikatakan produksi bertambah, jadi perhitungan $z_{3}$ menggunakan fungsi keanggotaan $(\mu)$ produksi bertambah.

$$
\begin{aligned}
& \text { uprdBertambah }[z]=\frac{z_{4}-300}{9.700} \\
& \mu p r d B e r t a m b a h[z] \times 9.700=z_{4}-300 \\
& z_{4}=(\mu p r d B e r t a m b a h[z] \times 9.700)+300
\end{aligned}
$$


JRI: Jurnal Rekayasa Industri, Vol. 1 No. 1 Oktober 2019

$$
\begin{aligned}
& z_{4}=(0 \times 9.700)+300 \\
& z_{4}=300
\end{aligned}
$$

Pada perhitungan $z_{3}$ diperoleh persamaan $z_{4}=(\mu p r d B e r t a m b a h[z] \times 9.700)+300$, maka dapat dibuat formula sebagai berikut:

$$
\begin{aligned}
& =\mathrm{IF}(\text { Sheet1 } \text { \$ J \$34="BERKURANG",\$AF\$43-((\$AF\$43-\$AF\$44)*V6),IF(Sheet1 } \\
& \text { !\$J \$34="BERTAMBAH",((\$AF\$43-\$AF\$44)*V6)+\$AF\$44)) }
\end{aligned}
$$

\subsection{Defuzzyfikasi}

Defuzzyfikasi dilakukan dengan persamaan 5, yaitu:

$$
Z=\frac{\sum_{i=1}^{n} \alpha_{i} z_{i}}{\sum_{i=1}^{n} \alpha_{i}}
$$

Dimana $\alpha_{i}$ adalah nilai keanggotaan $\mu$ dari setiap variabel dan $z_{i}$ adalah hasil dari inferensi sistem. Berikut merupakan perhitungan defuzzyfikasi untuk kapasitas produksi tanggal 1 Januari 2019.

$$
\begin{aligned}
Z_{1} & =\frac{z_{1} \times \alpha_{p 1}+z_{2} \times \alpha_{p 2}+z_{3} \times \alpha_{p 3}+z_{4} \times \alpha_{p 4}}{\alpha_{p 1}+\alpha_{p 2}+\alpha_{p 3}+\alpha_{p 4}} \\
Z_{1} & =\frac{1.784,01 \times 0,85+1.784,01 \times 0,15+10.000 \times 0+300 \times 0}{0,85+0,15+0+0} \\
Z_{1} & =1.784,01 \text { ton }
\end{aligned}
$$

\begin{tabular}{|c|c|c|c|}
\hline TGL & $\begin{array}{l}\text { Defuzzyfikasi Kap. Produksi } \\
\text { (ton) }\end{array}$ & $\begin{array}{l}\text { Persediaan Awal } \\
\text { (ton) }\end{array}$ & $\begin{array}{l}\text { Persediaan Akhir } \\
\text { (ton) }\end{array}$ \\
\hline 1 & $1.784,01$ & $33.552,15$ & $35.754,73$ \\
\hline 2 & $4.355,12$ & $35.754,73$ & $34.567,49$ \\
\hline 3 & $3.966,75$ & $34.567,49$ & $31.992,13$ \\
\hline 4 & $4.006,73$ & $31.992,13$ & $29.353,14$ \\
\hline 5 & $4.491,92$ & $29.353,14$ & $29.251,5$ \\
\hline 6 & $4.025,99$ & $29.25,5$ & $29.784,2$ \\
\hline 7 & $4.382,83$ & $29.784,2$ & $27.819,09$ \\
\hline 8 & $4.123,30$ & $27.819,09$ & $25.336,44$ \\
\hline 9 & $4.950,61$ & $25.336,44$ & $23.171,31$ \\
\hline 10 & $5.398,99$ & $23.171,31$ & $20.805,51$ \\
\hline 11 & $5.585,25$ & $20.805,51$ & $18.600,25$ \\
\hline 12 & $5.674,92$ & $18.600,25$ & $19.062,38$ \\
\hline 13 & $4.563,50$ & $19.062,38$ & $20.420,41$ \\
\hline 14 & $4.206,37$ & $20.420,41$ & $19.561,44$ \\
\hline 15 & $4.425,96$ & $19.561,44$ & $17.355,51$ \\
\hline 16 & $4.189,40$ & $17.355,51$ & $14.385,65$ \\
\hline 17 & $5.135,06$ & $14.385,65$ & $12.524,51$ \\
\hline 18 & $5.028,68$ & $12.524,51$ & $11.203,87$ \\
\hline 19 & $4.711,20$ & $11.203,87$ & $12.158,18$ \\
\hline 20 & $3.618,18$ & $12.158,18$ & $14.273,22$ \\
\hline 21 & $3.363,88$ & $14.273,22$ & $14.848,16$ \\
\hline 22 & $3.972,51$ & $14.848,16$ & $14.143,58$ \\
\hline 23 & $4.274,02$ & $14.143,58$ & $12.570,55$ \\
\hline 24 & $3.739,37$ & $12.570,55$ & $12.359,87$ \\
\hline 25 & $3.867,42$ & $12.359,87$ & $11.918,96$ \\
\hline 26 & $3.277,42$ & $11.918,96$ & $13.013,64$ \\
\hline 27 & $2.487,63$ & $13.013,64$ & $16.146,82$ \\
\hline 28 & $3.819,67$ & $16.146,82$ & $15.687,83$ \\
\hline 29 & $4.317,55$ & $15.687,83$ & $13.995,58$ \\
\hline 30 & $4.236,28$ & $13.995,58$ & $12.559,79$ \\
\hline 31 & $4.079,42$ & $12.559,79$ & $11.571,23$ \\
\hline Rata-Rata & $4.195,48$ & $30.967,99$ & $30.939,99$ \\
\hline
\end{tabular}

Contoh formula yang terbentuk dari persamaan ini untuk kapasitas produksi tanggal 1 Januari 2019 adalah sebagai berikut:

$$
=((\mathrm{W} 6 * \mathrm{~N} 6)+(\mathrm{O} 6 * \mathrm{X} 6)+(\mathrm{P} 6 * \mathrm{Y} 6)+(\mathrm{Q} 6 * \mathrm{Z6})) / \mathrm{SUM}(\mathrm{N} 6: \mathrm{Q} 6)
$$

Setelah memperoleh hasil $Z_{1}$ maka dapat diperoleh hasil persediaan untuk tanggal 2 Januari dan seterusnya. Berikut ini adalah tampilan hasil perhitungan dari $Z_{i}$.

Tabel 6. Hasil Defuzzyfikasi 
Hasil defuzzifikasi $\left(Z_{i}\right)$ merupakan hasil akhir output yang berupa nilai kapasitas produksi berdasarkan fuzzy inference system metode Tsukamoto. Hasil dari persediaan akhir diperoleh dari total persediaan awal ditambah kapasitas produksi dan dikurangi permintaan.

\section{Simpulan}

Hasil kapasitas rata-rata produksi semen PPC menggunakan metode fuzzy infrence system-Tsukamoto sebesar 4.195,48 ton/hari yang memberikan rata-rata persediaan akhir semen PPC 30.939,99 ton, dengan persediaan minimum $26.538,41$ ton dan maksimum $33.968,16$ ton. Jumlah persediaan tersebut menandakan bahwa kapasitas produksi tersebut dapat dikatakan sebagai kapasitas produksi yang optimum.

\section{DAFTAR PUSTAKA}

[1] Anggun, A., Fitri, M., \& Indra, D., 2016, "Sistem Penunjang Keputusan Pembelian Smartphone dengan Menggunakan Metode Fuzzy Tsukamoto". Jurnal Teknika. Hal. 37-32.

[2] Bahroni, A., Farmadi, A., \& Nugroho, R. A., 2016, "Prediksi Permintaan Produk Mie Instan dengan Metode Fuzzy Takagi-Sugeno", Jurnal Ilmu Komputer. Vol. 3 No. 2. Hal. 220-230.

[3] Kaswidjanti, W., Aribowo, A.S., \& Wicaksono, C.B., 2015, "Implementasi Fuzzy Inference System Metode Tsukamoto pada Pengambilan Keputusan Pemberian Kredit Pemilikan Rumah". Jurnal Telematika. Vol. 10 No. 2. Hal. 137-146.

[4] Kusumadewi, S., \& Hari P., 2013, Aplikasi Logika Fuzzy untuk Pendukung Keputusan (Ed. 2). Graha Ilmu. Yogyakarta.

[5] Mulyanto, A. \& Haris, A., 2016, "Penerapan Metode Fuzzy Tsukamoto untuk Menentukan Jumlah Jam Overtime pada Produksi Barang di PT Asahi Best Base Indonesia (ABBI) Bekasi”. Jurnal Informatika SIMANTIK. Vol. 1 No.1.

[6] Oktaviani, L., 2014, "Sistem Penentuan Perhitungan Jumlah Produksi Folding Gate Menggunakan Fuzzy Logic pada PT Jihan Jaya”, Jurnal Sistem Informasi. Vol. 1 No. 1. Hal. 12-15.

[7] Ramlan, R. \& Cheng, A. P., 2016, "The Conceptual Framework of Production Planning Optimisation Using Fuzzy Inference System with Tsukamoto", International Journal of Industrial Management (IJIM). Vol. 2. Hal. 80-91.

[8] Suyanto, 2007, Artificial Intelegent; Searching,Reasoning, Planing, and Learning. Bandung: Informatika. ISBN: 978-602-1514-44-3

[9] Yusida, M., dkk., 2017, "Implementasi Fuzzy Tsukamoto dalam Penentuan Kesesuaian Lahan untuk Tanaman Karet dan Kelapa Sawit”, Jurnal Ilmu Komputer (KLIKI). Vol. 4 No. 2. 